International Journal of Research in Advent Technology, Vol.7, No.5, May 2019

\title{
Hybrid Energy Generation Through Vertical Axis MAG Turbine and Solar Panel
}

\author{
Shweta K. Deshbhratar ${ }^{1}$, P.S. $\operatorname{Ardak}^{2}$ \\ P. G Student, P . R. Pote College of Engineering Amravati, India ${ }^{1,}$, \\ Profeesor-Department of Mechanical Engineering, P. R. Pote College of Engineering Amravati, India ${ }^{2}$ \\ Email: shwetaadce7@gmail.com ${ }^{1}$, pankajardak@gmail.com ${ }^{2}$
}

\begin{abstract}
The power demand in our country is increased hence there is consistent power cut in rural areas. This is because of high power consumption by factories and also due to less availability of non-renewable energy resources (1). To overcome this problem the application of hybrid renewable energy system to generate power at economic, quick, reliable answer to rural household's need for power. This Solar-Wind energy system can be considerably reducing of our power requirement in rural areas (2). But the wind speed is varying both day and night time top reduce electricity (3). To overcome this, issue the vertical axis MAG Wind Turbine (VAMWT) is proposed to used which reduces friction, as well as that horrible squeaking sound associated with roof mounted wind vents by combining both Wind Turbine (WT) and solar photo-voltaic (PV) (4). The hybrid controller has been selected for the rated power output of proposed system. The purpose of this work is power generation through VAMWT and PV hybrid system producing clean affordable electricity for home, farm, business . In this study optimized design of VAMWT has been selected and performance study is done with addition of PV panel and dc motor dynamo.
\end{abstract}

Index Terms- Energy Demand, Hybrid energy, photovoltaic, Wind Energy

\section{INTRODUCTION}

Power is most needed for our day to day life. The power generation is done either by conventional energy resources or by non-conventional energy resources. Electrical energy demand increases in world so to fulfill demand we have to generate electrical energy (1). Nowadays electrical energy is generated by the conventional energy resources like coal, diesel, and nuclear etc. The main disadvantage of these sources is that it produces waste like ash in coal power plant, nuclear waste in nuclear power plant and taking care of this wastage is costly (3). And it also damages the nature. The nuclear waste is very harmful to human being also. The conventional energy resources are depleting day by day. "Soon it will likely be completely vanishes from the earth so we ought to find another way to generate power (6). The new source have to be dependable, pollution free and reasonably priced. The nonconventional energy resources should be good alternative energy resources for the conventional energy resources (2). There are many non-conventional energy resources like geothermal, tidal, wind; solar etc., the tidal energy has drawbacks like it can only implemented on sea shores. While geothermal energy needs very lager step to extract heat from earth (3). Solar and wind are without problems available in all condition. The non-traditional power sources like sun, wind may be true opportunity source. But Solar energy has drawback it could not produce electrical energy in rainy and cloudy season so we need to overcome this drawback we can use two energy resources in order that any individual of source fails different supply will maintain producing the electricity. And in exact weather condition we are able to use each assets integrate"

\section{WIND ENERGY}

If the performance of a wind turbine is improved, then extra energy can be generated as a result decreasing the need for expensive power generators that cause pollution. This would also reduce the cost of power for the common people (2). The wind is actually there for the taking and doesn't value any cash. Power can be generated and stored by a wind turbine with little or no pollution (4). If the efficiency of the common place wind turbine is stepped forward and considerable, the common people can cut back on their power costs immensely (7). The types of wind turbines are Horizontal axis wind turbine, Vertical axis wind turbine. The vertical axis wind turbines are purely operates based on the drag force. But in horizontal axis wind turbines, lift and drag forces plays the roles to operate the wind turbines (3). The vertical axis wind turbines have less efficiency than horizontal axis wind turbines. But it has high maintenance cost and investment cost (4). To overcome these issues the vertical axis wind turbines are the best choice for wind energy generation at low cost.

\section{SOLAR ENERGY}

"Photovoltaic" is a merge of two words: "photo", meaning light, and "voltaic", meaning electricity (3). Photovoltaic technology, the scientific term used to describe what we use to convert solar energy into electricity, generates electricity from light $(\mathbf{8})$. We use a semi-conductor material which can be adapted to release electrons, the negatively charged particles that form the basis of electricity. The various types of PV Panels are single, poly, thin film amporous silicon panels. 


\section{HYBRID ENERGY SYSTEM}

Hybrid Energy system is the combination of electricity resources for giving energy to the burden. In other word it is able to described as Energy system that is fabricated or designed to extract energy via using two sources is called as the hybrid energy device (1). Hybrid electricity machine has proper reliability, performance, less emission, and decrease price (3). In this proposed system solar and wind power is used for generating power. Solar and wind has many advantages than other than any other non-conventional energy sources. Both the energy sources have greater availability in all areas (2). It needs lower cost. There is no need to find special location to install this system.

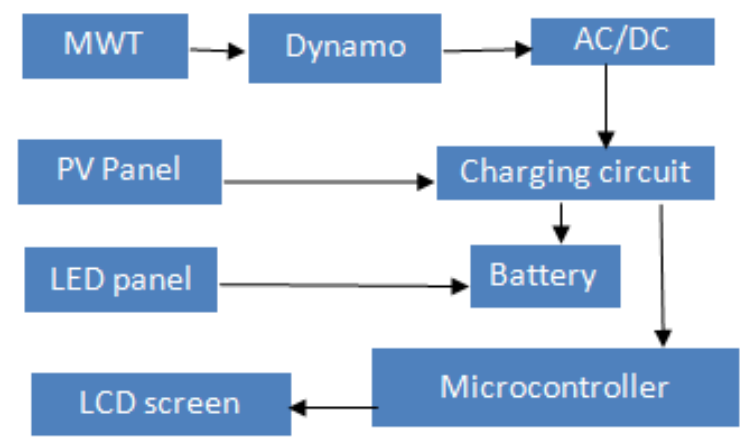

Figure1: Block Diagram of Hybrid System

\section{EXPERIMENTAL SETUP}

The block diagram of the system has shown in the Fig.1, and the fabricated model has shown in the Fig.2. Here the MAG turbine is mounted on block of $355.6 \mathrm{x}$ $355.6 \mathrm{~mm}$ made up of material WPC sheet at $90 \mathrm{~mm}$ height from block. And the PVC sheet has been selected with the thickness of $0.01 \mathrm{~mm}$ for the MWT blade. The Supporting base has been made by WPC material of thickness $12 \mathrm{~mm}$. Here the turbine has been connected with dynamo with the help of $\mathrm{v}$ belt which convert Kinetic energy of turbine into electrical energy which is stored in battery.

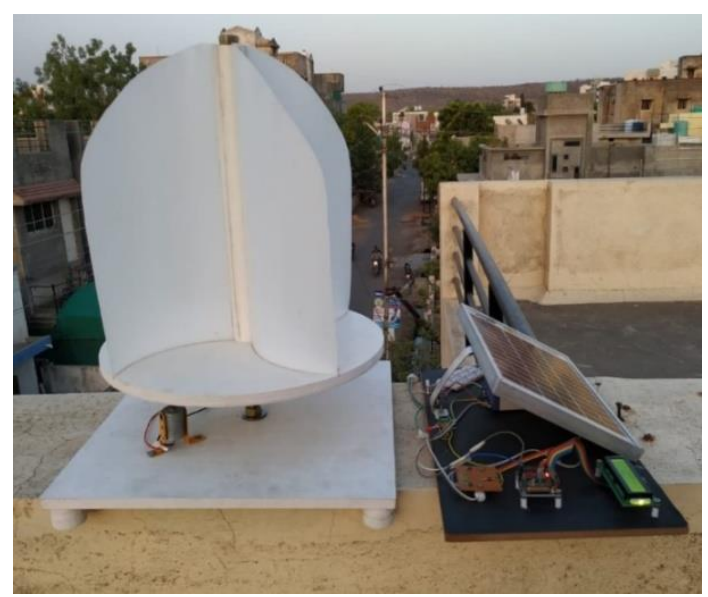

Figure 2: Fabricated model of Hybrid system

The specifications of the MWT, PV panel and the microcontroller have discussed in the Tables.1-3
Table.1. Specifications of wind turbine

\begin{tabular}{|c|c|c|c|}
\hline $\begin{array}{l}\text { Paramete } \\
\mathbf{r}\end{array}$ & $\begin{array}{l}\text { Dimension } \\
\text { s }\end{array}$ & Parameter & $\begin{array}{l}\text { Dimensi } \\
\text { ons }\end{array}$ \\
\hline $\begin{array}{c}\text { Rotor } \\
\text { diameter }\end{array}$ & $330.2 \mathrm{~mm}$ & $\begin{array}{l}\text { Blade } \\
\text { angle }\end{array}$ & 30 \\
\hline $\begin{array}{c}\text { Blade } \\
\text { height }\end{array}$ & $310 \mathrm{~mm}$ & $\begin{array}{l}\text { No. of } \\
\text { blade }\end{array}$ & 4 \\
\hline $\begin{array}{c}\text { Shaft } \\
\text { diameter }\end{array}$ & $34 \mathrm{~mm}$ & $\begin{array}{c}\text { Rotor } \\
\text { thickness }\end{array}$ & $12 \mathrm{~mm}$ \\
\hline
\end{tabular}

Table2. Specifications of the Selected Solar Panel

\begin{tabular}{|c|c|c|c|}
\hline Model & $\begin{array}{c}\text { AMV12V5 } \\
\text { W00522 }\end{array}$ & No. of cells & 36 \\
\hline $\begin{array}{c}\text { Maximum } \\
\text { power }\end{array}$ & 12 Watt & $\begin{array}{c}\text { Dimension } \\
(\mathrm{mm})\end{array}$ & $\begin{array}{c}285 \times 18 \\
5\end{array}$ \\
\hline Cell size & $\begin{array}{c}53 \times 17 \\
(\mathrm{~mm})\end{array}$ & $\begin{array}{c}\text { Weight } \\
(\mathrm{Kgs})\end{array}$ & $1 \mathrm{~kg}$ \\
\hline
\end{tabular}

Table 3: Specifications of the Microcontroller

\begin{tabular}{|c|c|c|c|}
\hline $\begin{array}{c}\text { Microcont } \\
\text { roller }\end{array}$ & ATmega328 & $\begin{array}{c}\text { Operating } \\
\text { voltage }\end{array}$ & $5 \mathrm{~V}$ \\
\hline $\begin{array}{c}\text { Input } \\
\text { voltage }\end{array}$ & $6-20 \mathrm{~V}$ & DC current & $40 \mathrm{MA}$ \\
\hline
\end{tabular}

Here the Vertical axis MAG turbine is used for domestic as well as industrial applications. The gear ratio used is 1:10. The experimental analysis is done and comparing the result with other type of turbine.

Analysis: The various measuring instruments used in this project. The wind velocity and speed of the wind turbine are measured by digital anemometer and digital tachometer with the range of $0-30 \mathrm{~m} / \mathrm{s}$ and $20-75000$ RPM. The wind and solar power outputs were measured by the microcontroller which is connected with charging circuit and shows the result on LCD screen.

The PV panel has been faced towards the south direction at an angle of $30^{\circ}$

\section{Theoretical Calculation for Wind Turbine:}

Vertical axis wind turbine power calculation:

$p=0.5 \rho A V 3$

Where, P-power,

$\rho-1.225 \mathrm{Kg} / \mathrm{m}^{3}$ density of air

A-Swept Area $\mathrm{m}^{2}$,

$\mathrm{V}$-wind velocity in $\mathrm{m} / \mathrm{s}$;.

MAG ar $=$ Swept area $=A=H X D$

Where, $\mathrm{H}=$ the blade height in $\mathrm{m}$,

$\mathrm{D}=$ the rotor diameter in $\mathrm{m}$.

$\mathrm{A}=0.31 \times 0.33=0.1023 \mathrm{~m} 2$

For wind velocity as $6 \mathrm{~m} / \mathrm{s}$.

Therotical Power $=0.5 \rho A V 3$

$=0.5 \times 1.225 \times 0.1023 \mathrm{X}^{3}$

$=13.53 \mathrm{Watt}$

Solar Power Calculation: 
Efficiency in PV panels is measured by the ability of a conversion.

$\eta \max =P \max / A c X G t$

Where, Pmax = Maximum power output in watts,

Ac $=$ Area of collector in $\mathrm{m} 2$,

$\mathrm{Gt}=$ Incident radiation flux in $\mathrm{W} / \mathrm{m} 2$,

$\eta=\mathrm{P} /$ AcXGt $=12 /(0.0527 \times 1100)=0.1897=18.97 \%$

Experimental Calculation of Wind Turbine:

$\mathrm{P}=\mathrm{V} \times \mathrm{I}$;

$\mathrm{P}=14.8 X 0.75 ; \mathrm{P}=11.1$ watts.

Experimental Calculation of Solar Panel:

Power $(\mathrm{P})=$ Voltage $(\mathrm{V}) \times$ Current $(\mathrm{I})$

$=15 \mathrm{X} 0.75=11.25$ Watts

Hybrid Power $=22.35$ watt

Testing-

For Mag Turbine

\begin{tabular}{|c|c|c|c|c|}
\hline $\begin{array}{l}\text { Sr. } \\
\text { No }\end{array}$ & $\begin{array}{c}\text { Wind } \\
\text { speed } \\
\text { (m/s) }\end{array}$ & $\begin{array}{c}\text { Speed of } \\
\text { rotor } \\
\text { (RPM) }\end{array}$ & $\begin{array}{l}\text { Voltag } \\
\text { e }\end{array}$ & \\
\hline 1 & 2 to 3 & 99 to 110 & 6 & \\
\hline 2 & 3 to 4 & 120 to 150 & 8.9 & \\
\hline 3 & 4 to 5 & 155 to 170 & 11.9 & \\
\hline 4 & 5 to 6 & 180 to 190 & 14.8 & \\
\hline 5 & 6 to 7 & 200 to 232 & 18 & \\
\hline 6 & 7 to 8 & 243 to 290 & 20 & \\
\hline
\end{tabular}

For Other Turbine (from 6)

\begin{tabular}{|c|c|c|c|}
\hline $\begin{array}{l}\text { Sr. } \\
\text { No }\end{array}$ & $\begin{array}{l}\text { Wind } \\
\text { (m/s) }\end{array}$ & $\begin{array}{l}\text { Speed of rotor } \\
\text { (RPM) }\end{array}$ & Voltage \\
\hline 1 & 2 to 3 & 109 to121 & 3.9 \\
\hline 2 & 3 to 4 & 189 to 201 & 4.8 \\
\hline 3 & 4 to 5 & 271 to320 & 6.2 \\
\hline 4 & 5 to 6 & 328 to353 & 8.8 \\
\hline 5 & 6 to 7 & 390 to 396 & 9.2 \\
\hline 6 & 7 to 8 & 400 to 409 & 12 \\
\hline
\end{tabular}

\section{CONCLUSION}

The VAWT is designed and fabricated in such a way that the it can able to capture wind from all the direction. This turbine gives more voltage at low rpm for same wind speed than traditional turbine and material used is light in weight and free from corrosion. This system is environmental friendly. The working model of our project is combined energy source with solar system and vertical axis wind turbine system, suppose anyone source fails to generate another source will keep generating the electricity and will give the continuous power to the load it is not. Our work and the consequences received are very endorsed that vertical axis wind energy conversion are plausible and probably very contribute to the production of the smooth renewable electricity from the wind even under low ideal sitting condition.

\section{FUTURE SCOPE}

This design of MAG wind turbine is readily fulfilled with improved design and suitable material, So as to give more efficiency than ordinary system and more researches have been developing to make it more feasible in future. So the efficiency of acquiring renewable energy increases.

\section{REFERENCES}

[1] Poorani.S, Professor-EEE-KAHE, Karpagam University, Coimbatore , Rajeswari KalliappanTNEB Executive, Hybrid Power Generation by Using Solar and Wind Energy Hybrid Power Generation Applicable To Future Electric Vehicle, International Journal of Emerging Trends in Science and Technology Vol.4 issue November 2017

[2] C. Bhuvaneswari and R. Rajeswari, Study Analysis of Study Analysis of Hybrid Power Plant (WindSolar) - Vertical Axis Wind Turbine Giromill Darrieus Type with Evacuated Tube Collectors, International Journal of Emerging Trends in Electrical and Electronics (IJETEE)Vol. 1, Issue. 1, March-2013

[3] Ragunath L. Emmanual L, Vignesh D, Hybrid Energy Generation through Vertical Axis Savonius Wind Turbine and Solar Panel, Journal of Chemical and Pharmaceutical Sciences

[4] Piyush Gulve, Dr. S. B, Barve, Design And Construction of Vertical Axis Wind Turbine, International Journal of Mechanical Engineering and Technology (IJMET), Volume 5.

[5] Arvind kumar, Sandip kumar singh, Wind power generation on highway. In IJIRST -International Journal for Innovative Research in Science \& Technology Volume1 Issue may2015

[6] Saurabh Arun Kulkarni Prof. M.R. Birajdar, Vertical Axis Wind Turbine for Highway Application, Imperial Journal of Interdisciplinary Research (IJIR) volume2 Issue 10, 2016

[7] Aman Jain, Aditya Gupta, Dinakar Singh, Kamal Sharma, REVIEW PAPER ON MAGLEV WIND TURBINE, International Research Journal of Engineering and Technology (IRJET) volume05 Issue 05 May 2018

[8] Rupesh S.Patil, Prof. Ashok Jhala , Prof. Manish Prajapati, Review paper for Grid Integration of Hybrid Generation International Research Journal of Engineering and Technology (IRJET) volume03 Issue 09-Sept-2016 